\title{
„Sehen und gesehen werden". Die Anfänge der Kino- und Filmkultur
}

Abstract: Der Beitrag widmet sich der Frage, wie und wo das um I90o neue Medium Film im Raum Niederösterreich präsentiert und rezipiert wurde. Hierbei werden die drei grundlegenden Aspekte der „Kinoöffentlichkeit“ berücksichtigt: Versammlungsöffentlichkeiten, reflexive Begleitöffentlichkeiten sowie Publikumsschichten. Ökonomische Überlegungen, technische Entwicklungen, behördliche Restriktionen und moralische Bedenken beeinflussten wechselseitig das jeweilige Filmprogramm sowie Vorführkonzeptionen und -orte. Das Kino ermöglichte neue Formen der Selbst- und Fremdwahrnehmung und erweiterte die eigene Lebenswelt. Vor allem die weibliche Schaulust irritierte „moralische Instanzen“. Wanderkinobetreiber*innen zogen durch das Land, drehten vor Ort Filme und ließen sich nach I9Io zusehends nieder. Mit der Etablierung fester Spielstätten setzte eine Verbürgerlichung des Kinos ein. Schließlich wird erstmals dargelegt, welche Filme in bzw. über Niederösterreich bis I9ı8 gedreht wurden.

"To See and to Be Seen". The Beginnings of Cinema and Film Culture. This chapter examines how and where the new medium of film was introduced, presented and received in Lower Austria around I900. The three basic aspects of the "cinema public" are considered: assembled audiences, reflexive public spheres and audience segments. Economic considerations, technical developments, official restrictions and moral concerns mutually influenced the respective cinema programmes as well as screening concepts and locations. Cinema enabled new forms of perception of the self and the outside world and expanded one's own world. Female curiosity in particular irritated "moral authorities". Travelling cinema operators toured the country, made films on location and became increasingly settled after roIo. With the establishment of permanent venues, a middle-class approach to cinema emerged. Finally, this chapter represents the first study of films shot in or about Lower Austria up to I9I8.

Keywords: early cinema, media history, social history, rural film culture, Austria

doi.org/10.52035/noil.2021.19jh02.26

Veröffentlicht nach externer Begutachtung (doppelblind) / published after external peer review (double blind) 